SAKAI SAMBAYAN — Jurnal Pengabdian kepada Masyarakat

\title{
PERBEDAAN EFEKTIFITAS POVIDONE IODINE DENGAN AIR REBUSAN DAUN BINAHONG TERHADAP PENYEMBUHAN LUKA PERINEUM PADA IBU POSTPARTUM DI BPM WILAYAH KERJA DINAS KESEHATAN KABUPATEN LAMPUNG SELATAN TAHUN 2017
}

\author{
Riyanti Imron $^{1}$, Risneni $^{1}$ \\ Dosen Jurusan Kebidanan Poltekkes Tanjungkarang
}

\begin{abstract}
Abstrak
Berdasarkan data Survey Demografi dan Kesehatan Indonesia (SDKI) jumlah laserasi atau luka perineum di Indonesia pada tahun 2013 menemukan bahwa dari total 1951 kelahiran spontan pervaginam, 57\% ibu bersalin mengalami rupture dan mendapat jahitan perineum (Depkes RI,2013). Upaya untuk mencegah terjadinya infeksi laserasi perineum dapat diberikan dengan terapi farmakologis iodine atau obat-obatan lainnya dan terapi non farmakologis berupa daun binahong. BPM Jamilah merupakan BPM yang ada di wilayah kerja Dinas Kesehatan Lampung Selatan, berdasarkan hasil presurvei awal pada bulan April di BPM Jamilah di dapatkan dara jumlah ibu yang melahirkan sebanyak 30 orang, yang mengalami rupture sebanyak 18 orang, rata - rata perawatan luka di berikan bethadin cair dan rata-rata penyembuhan luka perineum lebih dari 10 hari. Tujuan penelitian ini adalah ingin mengetahui perbedaan efektifitas povidone iodine dengan air rebusan daun binahong terhadap penyembuhan luka perineum pada ibu postpartum di BPM wilayah kerja Dinas Kesehatan Kabupaten Lampung Selatan Tahun 2017. Jenis penelitian ini menggunakan True Experimental post test only Design.. Populasi dalam penelitian ini seтиa ibu postpartum yang megalami laserasi perineum yang melahirkan pervaginam di BPM wilayah Kerja dinas Kesehatan Kabupaten Lampung Selatan. Sampel yang di ambil sebanyak 80 responden yang di bagi menjadi 2 kelompok dengan intervensi yang berbeda. yaitu 40 ibu post partum di berikan perawatan laserasi dengan Povidone Iodine dan 40 responden menggunakan rebusan Daun Binahong. Data yang di kumpulkan adalah data primer dengan 3 kali obsevasi. Data di olah dengan. menggunakan uji $T$ independen, proses pengolahan data menggunakan komputer. Hasil penelitian ini di dapatkan ibu post partum yang di berikan perawatan laserasi dengan Povidone Iodine lama penyembuhan luka yang terbanyak selama $\geq 7$ hari yaitu 38 responden (95\%) dengan rata- rata lama penyembuhan 8 hari, sedangkan responden menggunakan rebusan Daun Binahong penyembuhan luka terbanyak 5 hari dengan luka kering 20 responden (50\%).Lama penyembuhan rata-rata 5 hari. Berdasarkan hasil uji statistik dengan T Test diperoleh Uji beda $T$ test $p$ value $=0,000 .<0,05$ sehingga $H_{0}$ di tolak artinya, bahwa ada perbedaan yang signifikan antara penyembuhan luka perineum dengan menggunakan Povidone iodine dan air rebusan daun Binahong di Praktik Mandiri Bidan Kabupaten Lampung Selatan Tahun 2017. Peneliti menyarankan bagi petugas kesehatan terutama bidan agar terus meningkatkan penyuluhan/konseling serta perawatan luka perineum dengan menggunakan rebusan air rebusan daun binahong.
\end{abstract}

Kata kunci: Povidone Iodine ,Daun Binahong, Ibu nifas dengan luka perineum

\section{Pendahuluan}

Kasus laserasi atau luka perineum pada ibu bersalin tahun 2009 di seluruh dunia terjadi 2,7 juta orang. Angka ini diperkirakan mencapai 6,3 juta pada tahun 2050. Di Amerika 26 juta ibu bersalin yang mengalami laserasi perineum, $40 \%$ diantaranya mengalami laserasi perineum karena tehnik dalam menahan perineum pada saat persalianan kurang maksimal. Di Australia terdapat $20.000 \mathrm{ibu}$ bersalin yang mengalami laserasi perineum sedangkan di Asia laserasi perineum merupakan masalah yang cukup banyak dalam masyarakat, $50 \%$ di dunia terjadi di Asia (Hilmi, 2010). Di Asia rupture perineum juga merupakan masalah yang cukup banyak dalam masyarakat, $50 \%$ dari kejadian rupture perineum didunia terjadi di Asia (Campion, 2009). Berdasarkan data SDKI di Indonesia pada tahun 2013 di dapatkan hasil bahwa dari total 1951 kelahiran spontan pervaginam , 57\% ibu mendapat jahitan perineum $(28 \%$ karena 
episiotomi dan 29\% karena robekan spontan) (Depkes RI,2013).

Upaya untuk mencegah terjadinya infeksi laserasi perineum dapat diberikan dengan terapi farmakologis dan terapi nonfarmakologis. Terapi farmakologis adalah dengan pemberian obat antibiotik dan antiseptik (povidone iodine) untuk perawatan luka perineum akan tetapi obat dan bahan ini memiliki efek samping seperti alergi, menghambat pembuatan kolagen yang berfungsi untuk penyembuhan luka (Firdayanti, 2009). Sedangkan terapi nonfarmakologis yang dapat diberikan untuk mempercepat penyebuhan luka agar tidak terjadi infeksi adalah menggunakan daun binahong.

Berdasarkan data Profil Dinas Kesehatan Kabupaten Lampung Selatan pada tahun 2015 berhasil mengumpulkan data ibu nifas diantara nya adalah ibu nifas fisiologis sebanyak 3000 orang, ibu nifas dengan masalah antara lain yaitu ibu nifas 445 orang mengalami Bendungan ASI, 100 orang ibu nifas yang mengalami pusing, $25 \mathrm{ibu}$ nifas yang mengalami peningkatan suhu tubuh dan 66 ibu nifas yang mengalami mastitis, namun data tentang luka perineum ibu nifas belum ada pelaporan atau catatan yang lengkap dari setiap Puskesmas. Salah satu penyebabnya adalah karena lemahnya sistem pemantauan, pencatatan dan pelaporan petugas kesehatan dalam pelaksanaan pelayanan ibu masa bersalin dan nifas. (Dinkes Lampung Selatan, 2015).

Kabupaten Lampung Selatan merupakan kabupaten yang ada di provinsi Lampung yang terdiri dari 17 kecamatan di mana di setiap kecamatan terdapat sarana pelayanan kesehatan baik di puskesmas maupun BPM yang bertujuan untuk meningkatkan derajat kesehatan masyarakat. Saat ini jumlah BPM di Lampung Selatan sebanyak 56 BPM dan salah satunya adalah BPM Jamilah yang berada di wilayah kerja Puskesmas Palas. BPM Jamilah merupakan BPM yang memberikan pelayan kesehatan ibu dan anak, dan pelayanan yang di berikan di mulai dari ANC, Persalinan, Nifas, bayi, KB, Kespro KB. Berdasarkan hasil presurvei awal pada bulan April di BPM Jamilah di dapatkan dara jumlah ibu yang melahirkan sebanyak 30 orang, dan mendapat perawatan Nifas baik yang bersalin dengan luka jahitan maupun tidak dengan rata -rata perawatan 1 sampai 2 hari di BPM.

Dari 30 ibu postpartum tersebut ,yang mengalami rupture sebanyak 18 orang, dengan rincian rupture spontan sebanyak 10 orang dan yang di lakukan episiotomi 8 orang dan rata - rata perawatan luka di berikan bethadin cair. Menurut bidan BPM untuk angka kejadian infeksi puerperium (infeksi masa nifas) tidak ada catatan tertulis, tetapi dari jumlah ibu nifas tersebut ada terdapat 7 orang mengalami penyembuhan luka diatas 10 hari yaitu luka belum tertutup (belum kering). Apabila ada kejadian tersebut maka bidan praktik mandiri segera melakukan rujukan ke Puskesmas maupun ke dokter SpOG.

Berdasarkan uraian diatas maka penulis tertarik untuk melakukan penelitian dengan judul Perbedaan efektifitas povidone iodine dengan air rebusan daun binahong terhadap penyembuhan luka perineum pada ibu postpartum di BPM wilayah kerja Dinas Kesehatan Kabupaten Lampung Selatan Tahun 2017.

\section{Metode}

Rancangan penelitian yang digunakan adalah True Experimental post test only Design. Dikatakan true experimental (eksperimen yang sebenarnya/betul-betul) karena dalam desain ini peneliti dapat mengontrol semua variabel luar yang mempengaruhi jalannya eksperimen.

Responden sejumlah 80 ibu Post Partum dengan laserasi. Kelompok 1 sejumlah 40 orang, di beri intervensi povidone iodine dan kelompok 2 sejumlah 40 orang di beri intervensi air rebusan daun binahong.

Jenis penelitian analitk Analitik dengan Statistik Deskriptif dan bivariat denga Statistik Inferensial menggunakan uji $\mathrm{T}$ independen, proses pengolahan data menggunakan komputer.

\section{Hasil Penelitian}

\section{A. Hasil Analisis Univariat}

Tabel. 1. Distribusi Frekuensi Lamanya Penyembuhan Luka Perineum Dengan Povidone Iodine Di PMB Kabupaten Lampung Selatan Tahun 2017

\begin{tabular}{|c|c|c|}
\hline $\begin{array}{c}\text { Lama } \\
\text { Penyembuhan }\end{array}$ & f & $(\boldsymbol{\%})$ \\
\hline 3 hari & 0 & 0 \\
\hline 5 hari & 2 & 5 \\
\hline > 7 hari & 38 & 95 \\
\hline TOTAL & $\mathbf{4 0}$ & $\mathbf{1 0 0}$ \\
\hline
\end{tabular}

Dari tabel diatas dapat diketahui bahwa dari 40 responden yang di berikan perawatan luka perineum dengan povidone iodine yang terbanyak 
adalah ibu postpartum dengan lama penyembuhan luka selama $\geq 7$ hari yaitu 38 responden $(95 \%)$.

Tabel.2 Distribusi Frekuensi Rata-rata Lamanya Penyembuhan Luka Perineum Dengan Povidone Iodine Di PMB Kabupaten Lampung Selatan Tahun 2017

\begin{tabular}{|c|c|c|c|}
\hline Variabel & Mean & SD & $\begin{array}{c}\text { Minimal/ } \\
\text { maksimal }\end{array}$ \\
\hline $\begin{array}{c}\text { Povidoe } \\
\text { Iodine }\end{array}$ & $\mathbf{8 , 2 7 5 0}$ & $\begin{array}{c}- \\
\mathbf{9 6 0 4 4}\end{array}$ & $\mathbf{5 , 0 0 = 1 0 , 0 0}$ \\
\hline
\end{tabular}

Hasil analisis di dapatkan rata - rata lamanya penyembuhan luka dengan mengguna kan Povidone Iodine adalah 8,2750 hari (8 hari.) Lama penyembuhan paling cepat 5 hari dan yang paling lama 10 hari.

Tabel 3. Distribusi Frekuensi Lamanya Penyembuhan Luka Perineum Dengan Rebusan air Rebusan Di PMB Kabupaten Lampung Selatan Tahun 2017

\begin{tabular}{|c|l|l|}
\hline $\begin{array}{c}\text { Lama } \\
\text { Penyembuhan }\end{array}$ & $\mathbf{f}$ & $\mathbf{\%}$ \\
\hline 3 hari & 17 & 42,5 \\
\hline 5 hari & 20 & 50 \\
\hline 7 hari & 3 & 7,5 \\
\hline TOTAL & $\mathbf{4 0}$ & $\mathbf{1 0 0}$ \\
\hline
\end{tabular}

Dari tabel diatas dapat diketahui bahwa dari 40 responden yang di berikan perawatan luka perineum dengan rebusan daun Binahong terdapat yang terbanyak adalah ibu postpartum dengan lamanya penyembuhan luka selama 5 hari dengan luka kering sebanyak 20 responden $(50 \%)$.

Tabel 4. Distribusi Frekuensi Rata-rata Lamanya Penyembuhan Luka Perineum Dengan Air Rebusan Daun Binahong Di BPM Kabupaten Lampung Selatan Tahun 2017

\begin{tabular}{|c|c|c|c|}
\hline Variabel & Mean & SD & $\begin{array}{c}\text { Minimal/ } \\
\text { maksimal }\end{array}$ \\
\hline $\begin{array}{c}\text { Air Rebusan } \\
\text { Daun } \\
\text { Binahong }\end{array}$ & $\mathbf{4 , 8 7 5 0}$ & $\mathbf{1 , 2 6 4 6 6}$ & $\mathbf{3 , 0 0}=\mathbf{8 , 0 0}$ \\
\hline
\end{tabular}

Hasil analisis di dapatkan rata-rata lamanya penyembuhan luka dengan menggunkan air rebusan binahong adalah 4,8750 hari(5 hari).

Lama penyembuhan paling cepat 3 hari dan yang paling lama 8 hari.

\section{B. Analisis Bivariat}

Analisis bivariat untuk mengetahui perbedaan efektifitas povidone iodine dengan air rebusan daun binahong terhadap penyembuhan luka perineum pada ibu postpartum di BPM wilayah kerja Kabupaten Lampung Selatan Tahun 2017.

Tabel 5. Perbedaan Lamanya Penyembuhan luka perineum dengan Povidone iodine dan air rebusan daun Binahong di Kabupaten Lampung Selatan Tahun 2017 ( $\mathrm{n}=80$ )

\begin{tabular}{|c|c|c|c|c|c|}
\hline \multirow{4}{*}{ Lama penyembuhan luka Perineum } & Media Perawatan & N & Mean & Std. Deviation & $\boldsymbol{P} \boldsymbol{V}$ \\
\cline { 2 - 6 } & Povidone Iodine & 40 & 8.2750 & 0.9604 & 0,000 \\
\cline { 2 - 6 } & Air rebusan Daun Binahong & 40 & 4.8750 & 1.2646 & $\begin{array}{c}2.90012- \\
3.89988)\end{array}$ \\
\cline { 2 - 6 } & \multirow{2}{*}{ TOTAL } & $\mathbf{8 0}$ & & & \\
\hline
\end{tabular}

Berdasarkan tabel di atas rata - rata lamanya perawatan dengan meng gunakan Povidone Iodine 8,2750 (8 hari) dengan standar deviasi 0.96044, sedangkan lama perawatan dengan rebusan air daun binahong rata -rata 4.8750 (5 hari) dengan standar deviasi 4.8750. Hasil uji statistik dengan $\mathrm{T}$ Test diperoleh Uji beda T test $p$ value $=0,000 .<0,05$ sehingga $\mathrm{H}_{0}$ di tolak artinya, bahwa ada perbedaan yang signifikan antara penyembuhan luka perineum dengan menggunakan Povidone iodine dan air rebusan daun Binahong terhadap penyembuhan luka perineum pada ibu postpartum di PMB Kabupaten Lampung Selatan Tahun 2017. Sehingga peneliti dapat menyiimpulkan bahwa perawatan luka perineum dengan menggunakan air rebusan binahong lebih cepat kering di bandingkan dengan menggunakan povidone iodine.

\section{Pembahasan}

A. Analisis Univarat

1. Pembahasan Univarat

Hasil analisis di dapatkan rata-rata lamanya penyembuhan luka dengan menggunakan Povidone 
Iodine adalah 8,2750 (8 hari). Lama penyembuhan paling cepat 5 hari dan yang paling lama 10 hari. Berdasarkan hasil penelitian di dapatkan dari 40 responden yang di berikan perawatan luka perineum dengan povidone iodine yang terbanyak adalah ibu postpartum dengan lama penyembuhan luka selama $\geq 7$ hari yaitu 38 responden $(95 \%)$.

Hasil analisis di dapatkan rata-rata lamanya penyembuhan luka dengan menggunakan air rebusan binahong adalah 4,8750 (5 hari). Lama penyembuhan paling cepat 3 hari dan yang paling lama 8 hari. Berdasarkan hasil penelitian di dapatkan dari 40 responden yang di berikan perawatan luka perineum dengan rebusan daun Binahong terdapat yang terbanyak adalah ibu postpartum dengan lamanya penyembuhan luka selama 5 hari dengan luka kering sebanyak 20 responden $(50 \%)$.

\section{Pembahasan Bivariat}

Hasil uji statistik dengan $\mathrm{T}$ Test diperoleh Uji beda T test $p$ value $=0,000 .<0,05$ sehingga $\mathrm{H}_{0}$ di tolak artinya, bahwa ada perbedaan yang signifikan antara penyembuhan luka perineum dengan menggunakan Povidone iodine dan air rebusan daun Binahong di Kabupaten Lampung Selatan Tahun 2017.

Hasil penelitian Nurul dan Anisa (2007), menyebutkan bahwa dalam simplisia daun binahong terkandung senyawa saponin, alkaloid, dan polifenol. Saponin berfungsi sebagai pembersih dan mampu memacu pembentukan kolagen I, yang merupakan sebuah protein yang berperan dalam proses penyembuhan luka. Sebagai obat luka, binahong menagdung beberapa kandungan kimia yaitu flvonoid, asam oleanolik, protein, saponin, dan asam askorbat. Kandungan asam askorbat pada tanaman ini penting untuk mengaktifkan enzim prolil hodroksilasi yang menunjang tahap hidroksilasi dalam pembentukan kolagen, sehingga dapat mempercepat proses penyembuhan luka (susetya, 2012).

Hasil penelitian Ns. Kartika Wijayanti, M.Kep dan Dr. Heni Setyowati Esti Rahayu, S.Kp.,M.Kes dengan judul Efektifitas Air Rebusan Daun Binahong Terhadap Penyembuhan Luka Perineum Di Rumah Bersalin Aesya Grabag Kabupaten Magelang tahun 2016 di dapatkan hasil setelah diberikan intervensi air rebusan daun binahong, repsonden dengan penyembuhan luka perineum kategori sedang berjumlah 2 orang
(9.1\%) dan penyembuhan luka perineuam kategori baik berjumlah 20 orang (90.9\%). Responden yang diberikan intervensi bethadine, penyembuhan luka perineum kategori sedang berjumlah 12 orang $(54.5 \%)$ dan penyembuhan luka kategori baik berjumlah 10 orang $(45.5 \%)$ dengan $\mathrm{p}$ value $=0,021$ yang artinya bahwa ada perbedaan penyembuhan luka perineum yang bermakna setelah diberikan intervensi air rebusan daun binahong dan bethadine. Persentasi reponden yang mengalami penyembuhan luka perineum pada kelompok binahong, lebih baik daripada kelompok bethadine.

Beberapa penelitian yang telah dilakukan sebelumnya antara lain oleh Miladiyah (2012), yang menyatakan bahwa ekstrak etanol daun binahong mampu menyambuhkan luka lebih baik daripada povidoe iodine pada kulit kelinci. Penelitian tersebut juga didukung oleh Kaur (2014), menyatakan bahwa aplikasi pasta daun binahong secara topikal menunjukkan hasil lebih baik dalam proses penyambuhan luka dibandingkan dengan $\mathrm{Na} \mathrm{Cl}$ 0,9\% dan povidone iodine $5 \%$ pada kulit tikus, sehingga bisa digunakan sebagai alternatif pengobat luka di rumah yang bersifat tradisional.

Penelitian lain juga mendukung hal tersebut dilakukan oleh Oriza (2015), yang menyatakan bahwa ekstrak daun binahong dapat memperecepat penyembuhan luka sayat pada tikus putih dengan dosis efeltif yaitu konsentrasi 30\%, dibandingkan dengan povidone iodine. Penelitian lain dilakukan oleh Firzanah (2015), yang menyatakan bahwa ada pengaruh mengkonsumsi air rebusan daun binahong terhadap penyembuhan luka perineum pada ibu nifas.

Kandungan metabolit sekunder dari tumbuhan dapat digunakan untuk mengobati berbagai penyakit. Dari hasil uji fitokimia sebelumnya menunjukkan bahwa pada ekstrak daun binahong positif mengandung senyawa aktif saponin, flavonoid, steroid, terpenoid, fenol, dan alkaloid (Astuti, 2012). Polifenol dan saponin berfungsi sebagai anti bakteri (Wardani, 2012).

Ekstrak etanol daun binahong juga memiliki kapasitas sebagai antioksidan (Selawa, 2013). Pemberian daun binahong pada luka membantu penyembuhan luka dengan pembentukan jaringan granulasi yang lebih banyak dan reepitalisasi terjadi lebih cepat dibandingkan dengan luka yang tidak diberi daun binahong (Ariani, 2013). Saponin merupakan senyawa 
glikosida triterpenoida ataupun glikosida steroida yang merupakan senyawa aktif permukaan dan bersifat sperti sabun serta dapat dideteksi berdasarkan kemampuannya membentuk busa dan menghemolisa sel darah merah. Pola glikosida saponin kadang-kadang rumit, banyak saponin yang mempunyai satuan gula sampai lima dan komponen yang umum ialah asam glukoronat (Harborne, 1996). Berdasar struktur kimianya, saponin di kelompokkan menjadi 3 kelas utama yaitu kelas steroid, kelas steroid alkaloid, dan kelas triterpenoid ( Wallace et al., 2002).

Povidone Iodine merupakan substansi kimia polivinilpirolidon (juga dikenal sebagai Povidone dan PVP) dan Iodine elemental. Contoh dari Povidone Iodine termasuk dressing seperti Inadine ${ }^{\circledR}$ dan larutan seperti Betadine ${ }^{\circledR}$ dan Braunol®. Jenis Iodine kedua yang digunakan dalam balutan luka yaitu Cadexomer Iodine sebuah kombinasi Iodine dan polisakarida kompleks, seperti Iodoflex ${ }^{\circledR}$ dan Iodosorb ${ }^{\circledR}$, yang dapat digunakan sebagai antiseptik, khususnya di luka berongga. Iodine jenis ini dapat menyerap eksudat, dan melepaskan ion Iodine secara bertahap, memungkinkan efek antiseptik Iodine bertahan lebih lama dan memerlukan lebih sedikit penggantian balutan pada luka.

Efek samping Cadexomer Iodine yaitu rasa nyeri seperti terbakar pada area luka, kemerahan dan eczema. Studi mengenai keamanan Iodine menunjukkan resiko minimal pada fungsi tiroid. Cadexomer Iodine berguna saat mengobati luka yang terinfeksi dengan jumlah eksudat sedang hingga basah. Kemampuannya untuk melepaskan ion Iodine secara perlahan menyebabkan Iodine jenis ini dianjurkan untuk digunakan pada luka kronis di mana tidak diperlukan penggantian balutan yang sering. Pada penelitian ini penuyembuhan luka perineum yang tercepat adalah dengan menggunakan air rebusan daun binahong yaitu rata -rata 4,8750 (5 hari), di bandingkan dengan penyembuhan luka dengan menggunakan Povidone Iodine adalah 8,2750 (8 hari).

Berdasarkan uraian diatas dan membandingkan dengan teori maka penulis dapat menyimpulkan bahwa semakin responden secara rutin melakukan perawatan luka jahitan perineum dengan menggunakan air rebusan daun binahong lebih cepat penyembuhan luka perineum di bandingkan dengan povidone iodine. Hal ini di sebabkan karena dalam tumbuhan binahong sangat baik untuk revitalisasi kulit, memberi stamina ekstra, melancarkan peredaran darah, mengatasi pembengkakan dan pembekuan darah, memulihkan kondisi lemah, dan menyembuhkan luka. Penelitian. tentang daun binahong yang telah dilakukan salah satunya adalah penggunaannya untuk luka bakar (Ardiyanto, 2009).

Berdasarkan hasil penelitian maka peneliti menganjurkan pada ibu bersalin yang mengalami luka jahitan /laserasi jalan lahir derajat I dan II dapat melakukan perawatan luka dengan menggunakan rebusan air binahong sebagai antiseptic terhadap perawatan non farmaka untuk penyembuhan luka perineum sehingga penyembuhan luka perineum akan lebih cepat dan lebih baik lagi.

\section{Kesimpulan}

A. Simpulan

Berdasarkan hasil Penelitian dan pembahasan mengenai Perbedaan efektifitas povidone iodine dengan air rebusan daun binahong terhadap penyembuhan luka perineum pada ibu postpartum di Praktik Mandiri Bidan (PMB) wilayah kerja Dinas Kesehatan Kabupaten Lampung Selatan Tahun 2017, maka dapat di ambil kesimpulan sebagai berikut :

1. Dari 40 responden yang di berikan perawatan luka perineum dengan povidone iodine yang terbanyak adalah ibu postpartum dengan lama penyembuhan luka selama $\geq 7$ hari yaitu 38 responden $(95 \%)$.

2. Hasil analisis di dapatkan rata-rata lamanya penyembuhan luka dengan menggunakan Povidone Iodine adalah 8,2750 hari. Lama penyembuhan paling cepat 5 hari dan yang paling lama 10 hari.

3. Dari 40 responden yang di berikan perawatan luka perineum dengan rebusan daun Binahong terdapat yang terbanyak adalah ibu postpartum dengan lamanya penyembuhan luka selama 5 hari dengan luka kering sebanyak 20 responden $(50 \%)$.

4. Hasil analisis di dapatkan rata-rata lamanya penyembuhan luka dengan meng gunakan air rebusan binahong adalah 4,8750 hari. Lama penyembuhan paling cepat 3 hari dan yang paling lama 8 hari.

Hasil uji statistik dengan $\mathrm{T}$ Test diperoleh Uji beda T test $p$ value $=0,000 .<0,05$ sehingga $\mathrm{H}_{0}$ di tolak artinya, bahwa ada perbedaan yang signifikan antara penyembuhan luka perineum dengan 
menggunakan Povidone iodine dan air rebusan daun Binahong di Praktik Mandiri Bidan (PMB) Kabupaten Lampung Selatan Tahun 2017.

\section{B. Saran}

Berdasarkan hasil Penelitian, maka saran yang dapat penulis berikan setelah melakukan penelitian sebagai berikut :

1. Bagi Ibu Nifas

Penelitian ini di harapkan dapat meningkatkan pengetahuan serta dapat menjadi salah satu alternative dalam penyembuhan luka jahitan perineum dengan menggunakan air rebusan daun binahong saat masa nifas.

2. Bagi Tempat Penelitian Praktik Mandiri Bidan (PMB)

Bagi PMB Jamilah, SST , PMB Emalia Khaga A.Md.Keb, PMB Shindi Kristanty A.Md.Keb PMB Karmila, dan PMB Annisa Kholil, dapat memanfaatkan dan mengaplikasikan tehnik perawatan dengan menggunakan air rebusan daun binahong karena Banyak sekali manfaat daun binahong, dan sudah terbukti efektifitas daun binahong untuk penyembuhan luka khususnya luka perineum, sehingga perlu di terapkan di tempat praktik.

3. Bagi Institusi pendidikan Prodi Kebidanan Hasil penelitian ini di harapkan di jadikan wacana untuk menambah Wawasan/ilmu pengetahuan bagi mahasiswi Prodi Kebidanan Tanjungkarang khususnya mata kuliah asuhan kebidanan pada nifas tentang perawatan luka perineum dengan non farmako (penggunaan air rebusan binahong).

4. Bagi Peneliti Lain

Pada peneliti lain diharapkan dapat lebih baik dalam melakukan penelitian ini khususnya dalam meningkatkan penggunaan daun binahong dengan cara membuat ekstrak daun binahong dan melakukan kajian lebih lanjut, menggunakan metode yang lebih baik dan jumlah sampel yang lebih banyak lagi.

\section{Daftar Pustaka}

Arati Mahishale, Ashwini Chougala and Shobana Patted. 2013.Effect of Therapeutik Ultrasiund abd Maternal Cooling Gel Pad for Perineal Pain Following Vaginal Delivery With Episiotomy.J Women's Helath Care. https: //www.omicsgroup.org/.../effect-of- therapeuticultrasound-and-maternal-cooling.
Bobak, Lowdermilk, Jensen. 2005. Buku Ajar Keperawatan Maternitas Edisi 4. Jakarta : EGC BPOM,2015. Acuan sediaan herbal, http://www.scribb.com.Diakses tanggal 1 April 2015

Boyle, Maureen.2008. Pemulihan Luka. Jakarta: EGC

Budiarto, Eko. 2002. Biostatistika untuk Kedokteran dan Kesehatan Masyarakat. Jakarta: EGC

Carville K. 2007.Wound care:manual. $5^{\text {th }}$ ed.Osborne Park: Silver Chain Foundation.

Gurwinder Kaur a/p Gurcharan Singh, Novi Vicahyani, Hermin Aminah Usman. 2014. Effect of topical application of binahong (anredera cordifolia (Ten.). Sttenis Leaf Paste In Wound Healing Pricess In Mice. Althe medical juornal. Vol. 1 no.

http://journal.fk.unpad.ac.id/index.php/amj/article /view/289/285

Dahlan, M.S., (2010), Besar Sampel Dan Cara Pengambilan Sampel, dalam Penelitian kedokteran dan Kesehatan, Jakarta, Salemba Medika.

Davidson NS. REEDA: evaluating postpartum healing. J Nurs \& Midwif. 1974;19:68

Dedi Ardiyanto, 2009. Uji Aktivitas Krim Ekstrak Daun Binahong (Anredera Cordifolia (Ten) Steenis) Sebagai Penyembuh Luka Bakar Pada Kulit Punggung Kelinci, http://eprints.ums.ac.id/5168/

Fajar Kurniawan. 2013. Pengaruh salep eklstrak daun binahong (Anredera Cordifolia) Fraksi Etanol Terhadap Kesembuhan Luka Iris Secara Fisik Pada Anjing(Canis Familiaris). http: //etd.repository .ugm.ac.id/ index.php?mod=penelitian_detail\&sub=Peneliti an Detail \&act $=$ view\&typ= html\&buku_id=61229

Fya firzanah. 2015. Pengaruh Mengkonsumsi Air Rebusan Daun Binahong (Anredera Cordifolia (Ten.) Terhadap Penyembuhan Luka Perineum Pada Ibu Nifas Di BPS Ny. Dian Susiloririni, A.Md Keb. Nggronggot Nganjuk. Jurnal kebidanan Univ. Mayjen Sungkono Mojokerto. http:/ /unimas d3 bidan.blogspot.co.id/2013_06_23_archive.html

Hill P. Effect Of Hot And Cold On The Perineum After Episiotomy/Laceration. J Obstetri \& Gynecol Neonatal Nurs. 1989; 18: 124-129.

Hutchinson J.Phase of wound healings. [Online]. 1992 [Cited 2010 april 20]. Availabel from;URL http://www.clinimed.co.uk/woundcare/education/wound-essentials/phases-ofwound-healing.aspx

Isnatin Miladiyah. 2012. Ethanolic exctract of anredera cordifolia (Ten.) Steenis Leaves Improved Wound Healing In Guinea Pig. Universa Medicina vol. 31 no 1 January- April. 
www.univmed.org/wpcontent/uploads/2012/05/isnatin.pdf

Jensen et al, 2004, Maternity Nursing (Alih Bahasa Maria A Wijayarini dkk), Jakarta, EGC

Khunaifi, 2010.kandungan ekstrak daun binahong http:www.digilib.unimus.ac.id. Diakses tanggal 30 Maret 2015

Kususma Wardani, Nanik Sulistyani. 2012. Uji Aktifitas Antibakteri Ekstrak Etil Asetat Daun Binahong (Anredera Scandens (L) Moq.). Jurnal Ilmiah Kefarmasian UAD. Tehd shigella flexeneri beserta profil kromatologi lapis tipis

Khunaifi, M. 2010. Uji Aktifitas Antibakteri Ekstrak Daun Binahong (Anredera cordifolia (Ten.) Steenis) Terhadap Bakteri Staphylococcus aureus dan Pseudomonas aeruginosa. http://lib.uinmalang. ac.id /fullchapter /03520025.pdf.

Lenny, S. 2006. Senyawa Flavonoida, Fenilflavonoida dan Alkaloida. Jurnal Artikel Penelitian, (Online). http://www.usu.ac.id.

Lu Yu, Jingwei Xie, Na Xin, Zhanyou Wang, (2015), Panax Notoginseng Saponins Promote Wound Repair Of Anterior Cruciate Ligament Through Phosphorylation of PI3K, AKT and ERKInt $J$ Clin Exp Pathol.; 8(1): 441-449. https://www.ncbi.nlm.nih.gov/pmc/articles/PMC 4348819/

Mahlmeister, LR, and May, KA, (1990), Maternal and Neonatal Nursing: Family Centered Care, Third Edition, Lippincot Company, Philadelphia.

Manoi, F. 2009. Binahong (Anredera cordifolia (Ten) Steenis) Sebagai Obat. Jurnal Warta Penelitian Dan Pengembangan Tanaman Industri. Jurnal Artikel Penelitian, (Online). Volume 15 Nomor $1: 3$

Mochtar,Rustam.2002. Sinopsis Obstertri , Jakarta : EGC

Murray, S.S., Kinney, E.S. 2007. Foundation Of Maternal-Newborn Nursing, Singapore, Elsevier.

Prayudi, 2009. http:www//digilib.unimus.ac.id. Diakses tanggal 30 Maret 2015

Reeder Martin, Koniak, Griffin. 2012. Keperawatan Maternitas Kesehatan Wanita, Bayi \& Keluarga Volume 1 Edisi 18. Jakarta : EGC

Riset Kesedasar Provinsi Lampung (RISKESDAS), 2012

Shatana Saifuddin, Abdul Bari. 2009. Ilmu Kebidanan Sarwono Prawirohardjo. Jakarta: PT Bina Pustaka Sarwono Prawirohardjo

Saleha. 2009. Asuhan Kebidanan Pada Masa Nifas. Jakarta: Salemba Medika

Santram Lodhi, Avijeet Jain, Alok Pal Jain, Rajesh Singh Pawar, and Abhay Kumar Singhai.2016. Effects of Flavonoids From Martynia Annua and Tephrosia Purpurea On https:// www.ncbi. nlm.nih.gov/pmc/articles/PMC5052421/
Sastroasmoro, Sudigdo dan Ismael, Sofyan. 2011. Dasar-Dasar Metodologi Penelitian Klinis Edisi ke 4. Jakarta: Sagung Seto

Si YC. Li Q, Xie CE, Niu X, Xia XH and Yu CY. 2014. Chinese Herbs And Their Active Ingredients For Activating Xue (Blood) Promote The Proliferation And Diferentiation Of Neural Stem Cells And Mesenchymal Stem Cells Chin Med 2014; 9; 13

Suci Ariani. Khasiat Daun Binahong (Anredera Cordifolia (Ten.) Steenis) Terhadap Pembentukan Jaringan Granulasi Dan Reepitelisasi Penyembuhan Luka Terbuka Kulit Kelinci http: // ejournal. unsrat. ac.id /index. php/ ebiomedik/article/view/3250

Suci Ariani, Lily Loho, Meilany F Durry. (2013) Khasiat Daun Binahong (Anredera Cordifolia (Ten) Terhadap Pembentukan Jaringan Granulasi Dan Reepitalisasi Penyembuhan Luka

Sugiono, 2012, Statistika untuk penelitian. Alfabeta. Bandung

Suseno, 2013. Kandungan binahong.http : www.jurnal.stkipgarut.ac.id. Diakses tanggal 29 Maret 2015

Terbuka Kulit kelinci. http:/ /ejournal .unsrat. ac.id /index. php/ ebiomedik /article/ view/3250/2794

Sugiyono. 2013. Metode Penelitian Kuantitatif dan Kualitatif Dan R\&D. Cetakan Ke 8.Bandung: Alfabeta.

Susetya D. Khasiat Dan Manfaat Daun Ajaib Binahong Cetakan I, Yogyakarta, Pustaka Baru Press, 2012.

Steen M, Cooper K. A tool for assessing perineal trauma. J Wound Care. 1997; 6: 432-436. Trestiaty oriza. 2015. Pengaruh pemberian ekstrak daun binahong (Anrederacordifolia Ten.Steenis) Terhadap Gambaran Makroskopik Penyembuhan Luka Sayat Pada Tikus Putih (Rattus Norvegicus). http://repository.unhas.ac.id

Widya Selawa, Max Revolta John Runtuwene, Gayatri Citraningtyas 2013. Kandungan Flavonoid Dan Kapasitas Antioksidan Total Ekstrak Etanol Daun Binahong. Pharmacon, Jurnal Ilmiah Farmasi UNSRAT vol. 2 no. 1 februari 2013 ISSN 2302- 2493 http://ejournal.unsrat.ac.id/index.php/pharmacon/ article/viewFile/1018/831

Yellia Mangan, Nina Wulandari 2009. Solusi Sehat Mencegah dan Mengatasi Kanker, PT AgroMedia Pustaka, Tengerang. mangan,+ solusit mencegah+ kanker\&source =bl\&ots =yy8N9vV2og \&sig=XaJX7BXL3P

Yin LM, Wang X, Qian XD, Lin XJ, Chen XH and Gao RL. 2012. Effects of Phanax Notoginseng Saponin On Proliferation And Differentiation in NIH3T3 cells. Chin J Integr Med 2012; 18:616-620 
Zhuo N. Tang Y, Keep RF, Ma X and Xiang J. 2014. Anioxidative Effects Of Panax Notoginseng Saponins In Brain Celss.
Phytomedicine 2014, 21:1189-1195Simpan Sale Goreng Cianjur. Skripsi. IPB Bogor 